\title{
Decomposition rate of pigs' manures and nutrient release pattern in wetland condition
}

\author{
Bokossa Hervé Kouessivi Janvier ${ }^{1}$, Saïdou Aliou ${ }^{2,}$, , Fiogbé Emile Didier ${ }^{1}$, Kossou Dansou ${ }^{3}$ \\ ${ }^{1}$ Laboratory of Research on Wetlands (LRW), Department of Zoology, Faculty of Science and Technique, University of Abomey-Calavi, \\ Benin \\ ${ }^{2}$ Integrated Soil and Crop Management Unit (ISCM), Laboratory of Soil Sciences, Department of Crop Science, Faculty of Agronomic \\ Sciences, University of Abomey-Calavi, Benin \\ ${ }^{3}$ Laboratory of Plant Biology, Department of Crop Science, Faculty of Agronomic Sciences, University of Abomey-Calavi, Benin
}

\section{Email address:}

bokossakouessiv@yahoo.fr (Bokossa H. K. J.), saidoualiou@gmail.com (Saïdou A.), Edfiogbe@Yahoo.Fr (Fiogbe E. D.), kossoudansou@yahoo.com (Kossou D.)

\section{To cite this article:}

Bokossa Hervé Kouessivi Janvier, Saïdou Aliou, Fiogbé Emile Didier, Kossou Dansou. Decomposition Rate of Pigs' Manures and Nutrient Release Pattern in Wetland Condition. Agriculture, Forestry and Fisheries. Vol. 3, No. 4, 2014, pp. 271-278.

doi: $10.11648 /$ j.aff.20140304.19

\begin{abstract}
Recent studies reported the important contribution of animal dejections as organic manure for crop production but, little is known on the decomposition rate and nutrient release pattern in wetland of the manure of pigs nourished with diet enriched with Azolla filiculoides. A litter bag study was carried out under full control during 6 weeks in pots containing 25 liters of tap water and $15 \mathrm{~g}$ of pigs' dejection in each decomposition bag. The experimental design was a completely randomized block design with three replications. The treatments consisted of dejections of pigs nourished with : T1 (recommended diet composition) consisted of $15 \%$ Azolla $+55 \%$ provender $+5 \%$ coconut copra $+5 \%$ oil palm $+5 \%$ soybean bran $+10 \%$ rice bran $+5 \%$ kitchen waste ; T2 (partially improved diet with Azolla) consisted of 30\% Azolla $+65 \%$ rice bran $+5 \%$ oil palm; T3 (improved diet with Azolla) consisted of $47.5 \%$ Azolla $+47.5 \%$ rice bran $+5 \%$ oil palm; and T4 (improved diet with cereal bran) consisted of $15 \%$ Azolla $+40 \%$ rice bran $+40 \%$ wheat bran $+5 \%$ oil palm). Four pigs per diet were considered leading to 16 white landrace pigs of six months age. Decomposition rates in water were significantly $(\mathrm{P}<0.05)$ fast during the first week and became very slow during the following weeks. After the six weeks of experiment, $58.2 \%$ of manure from treatments T1 and T4 were decomposed against $47.2 \%$ for T2 and T3. However, 40.1, 53.3, 67.4 and $57.1 \%$ of total $\mathrm{N}$ content in treatments T1, T2, T3 and T4 respectively were released. As consequence, manure from improved diet with Azolla (T3 and T2) are suggested for integrated rice and fish production system. Nevertheless, decomposition and nutrients (P, $\mathrm{K}, \mathrm{Ca}$ and $\mathrm{Mg}$ ) release patterns had significantly $(\mathrm{P}<0.05)$ increased in water in treatments $\mathrm{T} 1$ and $\mathrm{T} 4$ compared with the two treatments containing more Azolla in the diet (T2 and T3).
\end{abstract}

Keywords: Pig Manures, Pig Diets, Azolla Filiculoides, Mineralization Rate, Nutrient Release, Wetland

\section{Introduction}

During the recent decades, an increase attention was paid to soil and water pollution by chemical fertilizer and pesticide using in intensive agricultural system [1]. Much researches put emphasized on nitrate leaching in agricultural land due to an increasing concentration in ground and drinking water [2] as result of livestock breeding intensification. This practice is responsible of most of the environmental damage caused to the terrestrial and marine ecosystems. In fact, it is generally attributed to the supply of increase nitrogen fertilizer [1]. This suggests alternative input environment friendly such as the use of organic residues from agricultural activities to improve land productivity and also fish production system. Manure and animal dejection can be an opportunity to supply nutrients especially $\mathrm{P}$ and $\mathrm{N}$ for crop production $[3,4,5]$. $\mathrm{N}$ release from organic wastes mineralization has been successfully tested in agriculture $[6,7,8,9,10]$. These authors concluded that, the supply of manure in agricultural land is an excellent way to recycle nutrients and organic matter to improve crop production. Generally, farmyard manures or compost are suggested as an alternative method for the management of these organic residues $[10,11]$. Knowledge on nutrients 
release from the decomposition and mineralization of organic manure is critical for the regulation of the ecosystem productivity, especially in nutrient-limited system.

However, [12] revealed that, rice-fish farming system constitutes an unique agro-landscape across the world, especially in tropical and sub-tropical area and the introduction of fish production to rice farming creates an integrated agro-ecological system. In that system, [13] found an increase of paddy rice yield compared with rice culture alone. It was also proved that, when the pigs were nourished with diet of high nutritive value such as Azolla filliculoides, it improves the quality of manure produced which could be used to feed fish and to supply nutrient to the crop in the wetland production system [14].

In such way, developing strategies to recycle nutrient from these residues especially those from livestock and pigs in the context of Benin agriculture is a challenge. However, in Benin, more than 518,600 pigs are breed with an increase of $3 \%$ the last four years $[16,17]$ leading to an important quantities of dejection produced which are source of environmental pollution. Furthermore, zooplankton production system based on the use of pigs' manure have been previously reported by [18] but, there is lack of knowledge on the decomposition and nutrient release pattern from animal manures especially pigs' dejection in the wetland for fish and rice production system.

This paper reports results of a study on the decomposition and nutrient release pattern of pigs' dejection in wetland condition using pots experiment. It aims to (i) study the decomposition rate in wetland condition of the manure of pigs nourished with diets of rice and wheat bran enriched with Azolla filiculoides, (ii) determine the amount of nutrients remain in the pigs' dejection during the decomposition process in the wetland condition and (iii) assess the amount of nutrient released in the water regarding the dejection of the pigs nourished with the different diets.

\section{Materials and Methods}

\subsection{Experimental Site}

The experiment was carried out on the site of the Laboratory of Research on Wetlands (LRW), Department of Zoology, Faculty of Science and Technique, University of Abomey-Calavi, Benin. It is located between $6^{\circ} 42^{\prime} \mathrm{N}$ and $2^{\circ} 34^{\prime} \mathrm{E}$ and $17 \mathrm{~m}$ asl. The area is characterized by sub-equatorial climate with two rainy seasons (March to end of July and mid-September to November) and two dry seasons (August to mid-September and December to March). Azolla filliculoides an aquatic fern used to enrich the pigs' diet was produced during three months (May to July 2013) in ponds on the experimental site.

\subsection{Pigs Feeding and Manure Collection}

Pigs feeding and manure collection according to the types of diet served to the animal were carried out on the experimental site. The manures were daily collected and mixed according to the diet served. They were collected from June to August 2013 and air dried at ambient temperature. About $50 \mathrm{~kg}$ of dejection were collected per types of diet given to the pigs. The diets were made based on results from experiments carried out by [17].

The diets consisted of recommended diet composition: $15 \%$ Azolla $+55 \%$ provender $+5 \%$ coconut copra $+5 \%$ oil palm $+5 \%$ soybean bran $+10 \%$ rice bran $+5 \%$ kitchen waste (T1); partially improved diet with Azolla: 30\% Azolla $+65 \%$ rice bran $+5 \%$ oil palm (T2); improved diet with Azolla : $47.5 \%$ Azolla $+47.5 \%$ rice bran $+5 \%$ oil palm (T3) and improved diet with cereal bran: $15 \%$ Azolla $+40 \%$ rice bran $+40 \%$ wheat bran $+5 \%$ oil palm (T4). The feeding experiment was carried out from May to August 2013. Four pigs white landrace of six months age per type of diet were considered leading to 16 animals were followed for manure collection.

\subsection{Experimental Design and Decomposition Process}

The experimental design was a completely randomized block design with three replications. The treatments consist of the different types of manure collected from the feeding experiment: $\mathrm{T} 1=$ recommended diet composition; $\mathrm{T} 2=$ partially improved diet with Azolla; T3 = improved diet with Azolla and T4 = improved diet with cereal bran.

Instead of plastic containers we used clay jars for the pot experiment as they create fresh condition like in the wetland. These clay jars were purchase in the village of Sè (South-West of Benin). The jars were filled with 25 liters of tap water [18]. Manure bags decomposition used in this experiment were constructed from nylon mosquito wire with a mesh size of 1 $\mathrm{mm}$. The nylon was tied and suspended in the tap water and also adapted from litter-bags techniques [19].

For each treatment, 12 manure nylon bags containing $15 \mathrm{~g}$ oven dried manure materials were filled. Manure nylon bags were randomly placed in the 12 clay jars of one lot to be sampled each week. In total, 6 lots of 12 clay jars leading to 72 clay jars were used during the experiment. Manure nylon bags were sampled at $6,12,18,24,30$ and 36 days, with one manure nylon bag randomly selected from each lot and transported to the laboratory for the analysis. During each sampling period, three manure nylon bags per treatment were collected. Furthermore, 15 water samples were also collected and sent to the laboratory for analysis.

Undecomposed manures were carefully put in aluminum crucible after removing the nylon bag and oven dried at $65^{\circ} \mathrm{C}$ for $72 \mathrm{~h}$ to determine manure mass remaining at the Laboratory of Wetland Research. The samples were then weighted to appreciate the weight losses. Samples were ground (mesh $0.1 \mathrm{~mm}$ ) and sent to the Laboratory of Soil Science Water and Environment of Benin National Agricultural Research Institute (LSSEE/INRAB) for nutrient analysis. Water samples were analyzed at the Laboratory of Water Analysis of the General Directorate of Water (DGE, in charge of drinking water control in Benin) at Cotonou. 


\subsection{Manure and Water Analysis}

The analyses were carried out on the undecomposed pigs' manure and water during the decomposition process. Methods used for the analysis of the undecomposed manure were that described by NF EN 14082 norm used at the LSSEE/INRAB's laboratory. The analyses were performed on: organic carbon (dry ashing in a muffle furnace at $550^{\circ} \mathrm{C}$ for $24 \mathrm{~h}$ then, organic matter is determined by the difference between the treated sample and the mass of ash obtained assigned an empirical coefficient of 2). The ash obtained was used for determination of $\mathrm{Ca}, \mathrm{Mg}, \mathrm{K}$ and $\mathrm{P}$ content in the manure. The ash was gathering in $6 \mathrm{~N} \mathrm{HCl}$ involving a period of heating at $125^{\circ} \mathrm{C}$ then the residue was dissolved in $1 \mathrm{~N}$ $\mathrm{HNO}_{3}$. $\mathrm{Ca}, \mathrm{Mg}$ and $\mathrm{K}$ were determined by atomic absorption spectrophotometry and $\mathrm{P}$ measured colorimetrically by ammonium molybdate with ascorbic acid at a wavelength of $660 \mathrm{~nm}$. Total $\mathrm{N}$ was determined using Kjeldahl digestion in a mixture of $\mathrm{H}_{2} \mathrm{SO}_{4}$ selenium followed by distillation and titration.

Water sample collected were stored in a fridge at $4^{\circ} \mathrm{C}$ for assessing nutrient released during the mineralization process. Analyses included suspended solids, $\mathrm{NO}_{3}{ }^{-}, \mathrm{NO}_{2}{ }^{-}$and $\mathrm{NH}_{4}{ }^{+}$ content. Suspended solids were measured using Standard NF EN 14082 method after water drying in an oven at $105^{\circ} \mathrm{C}$ for 24 hours followed by dry ashing of the residue in a muffle furnace at $550^{\circ} \mathrm{C}$ for 6 hours then, $\mathrm{C}$ content was determined. $\mathrm{NO}_{3}^{-}$using sodium salicylate method [20], nitrate ions in the presence of sodium salicylate form sodium paranitrosalicylate colored in yellow which is measured by colorimetry at a wavelength of $420 \mathrm{~nm} . \mathrm{NO}_{2}^{-}$using reagent of Zambely method [20] where ammonium ions in the presence of sulfanilic acid and phenol form a yellow colored complex which is measured by colorimetry at a wavelength of $435 \mathrm{~nm} . \mathrm{NH}_{4}{ }^{+}$by NESSLER method [20], ammonia in the presence of this reagent forms reddish-brown color which is measured by colorimetry at a wavelength of $425 \mathrm{~nm}$. $\mathrm{PO}_{4}{ }^{3-}$ using ammonium molybdate reagent the blue color was measured by colorimetry at a wavelength of $880 \mathrm{~nm}$.

$\mathrm{K}^{+}, \mathrm{Ca}^{2+}$ and $\mathrm{Mg}^{2+}$ content in water were determined by atomic absorption spectrophotometry. Temperature and dissolved oxygen were measured in situ using an oxythermometer (OXI 197i-N27455), conductivity using a conductimeter (N27444-197i) and $\mathrm{pH}$ with a $\mathrm{pH}$ meter (197i-N27499).

\subsection{Data Analysis}

Several models were tested using EXCEL software but it was found that, the single exponential equation provided a good fit of the different types of pigs' manures decomposition pattern in water over the complete time of observation (36 days) with coefficient of determination over $90 \%$. The following single exponential model was fitted to the data:

$$
\mathrm{Y}=e^{-k * t}
$$

Whereby, $\mathrm{Y}$ is the proportion of initial mass remaining at time $t$, and $k$ is the decomposition factor. To calculate the $k$ values, the formula was rewritten as:

$$
\ln \mathrm{Y}=-\mathrm{k} * \mathrm{t}
$$

Hence the slope of the line, calculated by linear regression, is the $k$ value.

The statistical analyses were performed using SAS 9.2 package. Analysis of variance was run on the decomposition data, nutrient remained in the manures and nutrient released in water considering time of decomposition and treatments (types of manure) as main factors, standard errors of the difference in means were calculated. The Student Newman-Keuls test was performed to compare differences in means among treatments. All significance levels were set at $P<0.05$.

\section{Results}

\subsection{Decomposition Pattern of the Different Types of Pigs' Manure in Water}

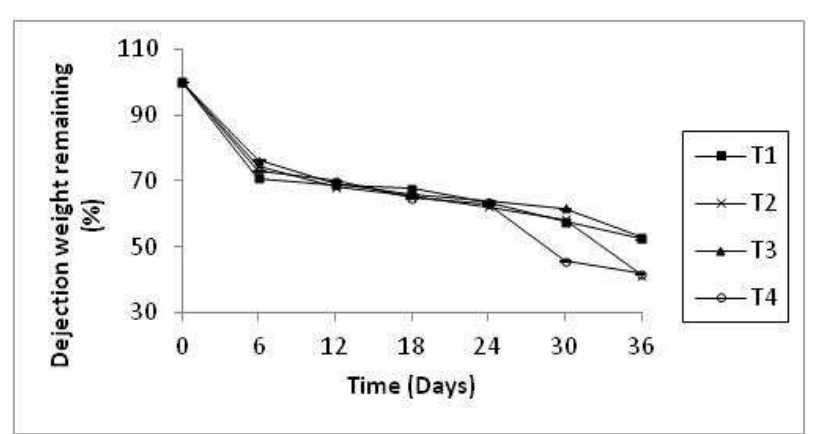

Figure 1. Decomposition pattern in water of manures from pigs nourished with different types of diet

Note: $\mathrm{T} 1=$ Manure of pigs nourished with recommended diet composition; $\mathrm{T} 2=$ manure of pigs nourished with diet partially improved with Azolla; T3 $=$ manure of pigs nourished with diet improved with Azolla ; T4 = manure of pigs nourished with diet improved with cereal bran.

The decomposition patterns i.e. mass remaining of the manure from pigs nourished with different types of diet are presented in Fig. 1. During the first week the graphs show similar and rapid decomposition of the manures in water. But, after two weeks, the decomposition trends were almost slow and do not vary significantly considering the manure types. Specifically, the decomposition pattern was steady from the second week until the fourth week. Then, the decrease of the mass remains were noticed with manure from pigs nourished with diet partially improved with Azolla (T2) and diet improved with cereal bran (T4) after five and six weeks of decomposition. The decomposition pattern of the manures from pigs nourished with diet improved with Azolla (T3) and manure of pigs nourished with recommended diet composition (T1) were almost similar after five and six weeks. Significant differences were noticed between treatments $\mathrm{T} 2$ and $\mathrm{T} 4$ in the one hand and treatments $\mathrm{T} 1$ and $\mathrm{T} 3$ in the other hand. Thus, at the end of the experiment, more than $41.8 \%$ of the mass of the manure from treatments $\mathrm{T} 4$ and $\mathrm{T} 2$ were not decomposed against 
more than $52.8 \%$ of the mass of the manure from treatments $\mathrm{T} 1$ and $\mathrm{T} 3$.

The decomposition constants $\mathrm{k}$ calculated for the different periods of experiment are presented in Table 1 . The $\mathrm{k}$ values decrease fast during the first week and slowly during the following five weeks as previously shown.

\subsection{Nutrient Remaining in the Manure}

The amount of nutrient remaining in the manure during the sampling periods is presented in Fig. 2. However, quantity of nutrient remained after the decomposition process is irregular over the time as shown with the decomposition rate. The losses of $\mathrm{N}, \mathrm{P}, \mathrm{K}, \mathrm{Ca}$ and $\mathrm{Mg}$ were significantly $(\mathrm{P}<0.05)$ fast during the first week of decomposition. From the second week to the subsequent weeks, nutrient concentration in the manure decreased slowly but, the amount remains relatively stable at the end of the experiment.

More than $50 \%$ of the $\mathrm{N}$ in the different manures was mineralized during the six weeks of the experiment with almost $50 \%$ of weight loss of the decomposed manure. This is much more important with manure of pigs nourished with diet improved with Azolla (T3 and T2). Considering the total amount of $\mathrm{N}$, it is observed a significant release for treatment $\mathrm{T} 3$ and $\mathrm{T} 2$ compared with treatments $\mathrm{T} 1$ and $\mathrm{T} 4$. However, the amount of $\mathrm{N}$ release in treatments $\mathrm{T} 1$ and $\mathrm{T} 4$ are similar meaning that, the low level of nitrogen source in the diet of the pigs affects significantly the decomposition rate of the manure in the water.

The total $\mathrm{P}$ released in the manure of treatment $\mathrm{T} 1$ was significantly $(\mathrm{P}<0.05)$ higher than that of treatments $\mathrm{T} 2, \mathrm{~T} 3$, T4. About $2 / 3$ of the initial contents of $P$ in the different types of manure were released from the beginning to the end of the experiment. For the different types of manure, after two weeks of decomposition, almost the total amount of $\mathrm{P}$ is released leading to weak amount of $\mathrm{P}$ remained in the manure from the $4^{\text {th }}$ to the $6^{\text {th }}$ week of decomposition. In total, the amount of $\mathrm{P}$ that remain in the manure after six weeks of decomposition in treatment $\mathrm{T} 1$ is 1.3 time significantly $(\mathrm{P}<0.05)$ higher than that of treatment $\mathrm{T} 2$ while it is almost similar with treatments T3 and T4.

The change in $\mathrm{K}, \mathrm{Mg}$ and $\mathrm{Ca}$ concentration during the decomposition process follow the same trend as that of $\mathrm{P}$ with high amount released with treatment $\mathrm{T} 1$ compared with treatments T2, T3 and T4. It is also observed that, about 2/3 of the initial $\mathrm{K}$ contents were released over the six weeks. In total, the amount of $\mathrm{K}$ remaining in the manure after six weeks of decomposition in treatment $\mathrm{T} 1$ is $2.4,2.6$ and 1.9 times significantly $(\mathrm{P}<0.05)$ higher than that of treatments T2, T3 and T4 respectively. However, the amount of $\mathrm{Ca}$ remaining in the manure after six weeks of decomposition in treatment $\mathrm{T} 1$ is $1.3,1.2$ and 1.4 times significantly $(\mathrm{P}<0.05)$ higher than that of treatments $\mathrm{T} 2, \mathrm{~T} 3$ and $\mathrm{T} 4$ respectively. Furthermore, the change with $\mathrm{Mg}$ content in the manure $\mathrm{T} 1$ which is the same with treatment $\mathrm{T} 3$ is $1.3,1.2$ times significantly $(\mathrm{P}<0.05)$ higher than that of $\mathrm{T} 2$ and $\mathrm{T} 4$.

\subsection{Effect on Water Quality}

Water chemical properties as affected by the manure decomposition process at the beginning and the end of the experiment are presented in Tables 2 and 3 . The decomposition of manure has significantly affected water quality despite the relative short period of decomposition. However, the different types of manure have induced significant increase in $\mathrm{N}$ fractions $\left(\mathrm{NH}_{4}{ }^{+}, \mathrm{NO}_{3}{ }^{-}, \mathrm{NO}_{2}{ }^{-}\right)$at the end of experiment. The $\mathrm{K}^{+}, \mathrm{Ca}^{2+}, \mathrm{Mg}^{2+}$ and phosphorus $\left(\mathrm{PO}_{4}{ }^{3-}\right)$ content in water at the end of the decomposition process of all of the manure of pigs nourished with different diets have also significantly $(\mathrm{P}<0.05)$ increased as induced by the large amount of nutrients released. This is much more important with treatment T1 compared with the other treatments.

We also observed an increase of the conductivity of the water induced by the decomposition of the manure as result of nutrient enrichment. However, manure from pigs nourished with diet improved with cereal bran (T4) presents the highest value of water conductivity compared with the other types of decomposed manure. The value of water conductivity in treatment $\mathrm{T} 4$ has significantly $(\mathrm{P}<0.05)$ increased by $1.5,1.14$ and 1.2 compared with treatments $\mathrm{T} 1$, $\mathrm{T} 2$ and $\mathrm{T} 3$ respectively.

The $\mathrm{pH}$ values as affected by the decomposition process of the manures have significantly increased along the six weeks of experiment. The values are almost greater than 7 leading to alkaline area induced by the manure in decomposition which has released large amount of $\mathrm{NH}_{3}$. The temperature fluctuates between 30 and $33^{\circ} \mathrm{C}$ reflecting the climatic condition during experimentation period. With regard to the suspended solids in the water, they present a remarkable increase between the beginning and the end of the experiment in all of the treatments. Manure from diet with high content of Azolla filiculoides (treatment T3 and secondarily T2) has release more suspended solids which were 1.4, and 1.3 times higher than treatments $\mathrm{T} 4$ and T1 respectively. Values of dissolved oxygen concentration increased significantly from the first day to the end of the experiment but, no significant $(\mathrm{P}>0.05)$ difference was observed between treatments.

\section{Discussion}

\subsection{Performance of the Decomposition Model Used}

The one component model $\mathrm{Y}=\mathrm{e}^{-\mathrm{k}^{*} \mathrm{t}}$ used also applied by [21] has been used to determine the mineralization constant $\mathrm{k}$. During the decomposition process a fast raise of the $\mathrm{k}$ values during the first week was observed then, the trends were progressively weak and constant until the end of the six weeks of observation. It was observed that, $\mathrm{k}$ is not constant during the time showing the weakness of the model used. However, [22] working in an aquatic environment indicated that, the rate of decomposition is not constant in the time and proposed the implication of several other constants and modified the formula developed by [23] suggesting the 
following equation: $\mathrm{Y}=\mathrm{Y}_{\mathrm{o}} * \mathrm{e}^{(\mathrm{ko} / \mathrm{b})(\mathrm{e}-\mathrm{bt}-1)}$ which was not applicable in the case of our study. Our results show a fast mineralization of labile fraction contained in the manure during the first week then, during the following weeks, a slow mineralization process of the fraction rich in carbon (i.e. having high $\mathrm{C} / \mathrm{N}$ ratio) until the end of the experiment. However, taking into account the various constituent of the organic residues, [19] studying the mineralization process of nitrogen in the organic residues suggested the following equation: $\mathrm{W}_{\mathrm{t}}=\mathrm{Ae}^{-\mathrm{k} 1 \mathrm{t}}+(1-\mathrm{A}) \mathrm{e}^{-\mathrm{k} 2 \mathrm{t}}$

where, $\mathrm{Wt}=$ percentage of weight loss at the time $\mathrm{t}, \mathrm{A}$ the labile portion in relation to the total mass, 1-A the ratio of the resistant fraction in the total weight, $\mathrm{k}_{1}$ the rate of decomposition for the labile fraction to fast deterioration within a year and $k_{2}$ for the rate of decomposition of the resistant fraction. As described, the equation suggested by [19] cannot be applied to short length experimentation. Nevertheless, the equation used in the present study has the merit to contribute in the raising of the mechanism of decomposition of the manure in water with the report of fast and fleeting mineralization process. This is very important when it comes to develop improving practice for fish and rice cultivation while limiting the risk of $\mathrm{N}$ volatilization. Furthermore, diets including rice bran, Azolla filiculoides and wheat bran were found to be an excellent practice which provides manure of good quality to be used in integrated fish-rice culture for saving resources.

\subsection{Mineralization Process and Nutrient Release as Affected by the Pigs' Diet}

Our study shows large differences in the chemical composition, decomposition patterns and water chemical properties as result of decomposition process of the manures $\mathrm{N}$ and $\mathrm{P}$ decreased fast at the first week and slowly for the last five weeks showing two phases of $\mathrm{N}$ mineralization. The works of [24] confirmed our result and revealed that, most of the $\mathrm{N}$ in green manure was mineralized shortly after application. These results were different from those found by [25] who found four phases of mineralization of litters.

This difference from our results can be due to the short time duration of the experiment and the decomposition environment. Beside the short duration of our study, one could mention watershed environment with probably different types of microorganism involved in the decomposition process compared with that of the soil.

Furthermore, [26] revealed that, higher microbial activity can be correlated with greater $\mathrm{N}$ release. In fact, low $\mathrm{C}$ : $\mathrm{N}$ ratio was found in all of the pig manures studied which could probably explain this fast mineralization trend observed during the first phase noticed. But in the second phase with the recalcitrant fraction of the manure the $\mathrm{C}: \mathrm{N}$ ratio becomes high due to the rapid loss of $\mathrm{N}$ as consequence, slow $\mathrm{N}$ release is noticed during the succeeding weeks of decomposition.

Table 1. Decomposition constants $\left(k\right.$.day $\left.{ }^{-1}\right)$ calculated for different periods $(t)$. Values were calculated with single exponential model $\left(Y=e^{-k^{*} t}\right)$, coefficient of determination $\left(R^{2}\right)$ indicates goodness of fit.

\begin{tabular}{|c|c|c|c|c|c|c|c|c|c|c|c|c|}
\hline \multirow{2}{*}{ Treatments } & \multicolumn{2}{|c|}{$t=6$ days } & \multicolumn{2}{|c|}{$t=12$ days } & \multicolumn{2}{|c|}{$t=18$ days } & \multicolumn{2}{|c|}{$t=24$ days } & \multicolumn{2}{|c|}{$t=30$ days } & \multicolumn{2}{|c|}{$t=36$ days } \\
\hline & $\mathbf{k}$ & $\mathbf{R}^{2}$ & $\mathbf{k}$ & $\mathbf{R}^{2}$ & $\mathbf{k}$ & $\mathbf{R}^{2}$ & $\mathbf{k}$ & $\mathbf{R}^{2}$ & $\mathbf{k}$ & $\mathbf{R}^{2}$ & $\mathbf{k}$ & $\mathbf{R}^{2}$ \\
\hline $\mathrm{T} 1$ & 5.72 & 0.84 & 3.10 & 0.84 & 2.16 & 0.84 & 1.89 & 0.84 & 1.83 & 0.84 & 1.78 & 0.84 \\
\hline $\mathrm{T} 2$ & 4.94 & 0.87 & 3.19 & 0.87 & 2.36 & 0.87 & 1.97 & 0.87 & 1.78 & 0.87 & 2.45 & 0.87 \\
\hline $\mathrm{T} 3$ & 4.48 & 0.87 & 3.08 & 0.87 & 2.30 & 0.87 & 1.86 & 0.87 & 1.61 & 0.87 & 1.77 & 0.87 \\
\hline T4 & 5.19 & 0.92 & 2.95 & 0.92 & 2.40 & 0.92 & 1.91 & 0.92 & 2.61 & 0.92 & 2.42 & 0.92 \\
\hline
\end{tabular}

$\mathrm{T} 1$ = manure of pigs nourished with recommended diet composition; T2 = manure of pigs nourished with diet partially improved with Azolla; $\mathrm{T} 3$ = manure of pigs nourished with diet improved with Azolla ; T4 = manure of pigs nourished with diet improved with cereal bran.

Table 2. Average value ( \pm standard errors) of water chemical ( $\left.m g . L^{-1}\right)$ properties at the beginning and the end of the decomposition process of manure of pigs nourished with different types of diet

\begin{tabular}{|c|c|c|c|c|c|c|c|c|}
\hline \multirow{2}{*}{ Treatments } & \multicolumn{2}{|l|}{$\mathrm{NO}_{2}^{-}$} & \multicolumn{2}{|l|}{$\mathrm{NO}_{3}^{-}$} & \multicolumn{2}{|l|}{$\mathrm{NH}_{4}{ }^{+}$} & \multicolumn{2}{|l|}{$\mathrm{PO}_{4}{ }^{3-}$} \\
\hline & Beginning & End & Beginning & End & Beginning & End & Beginning & End \\
\hline $\mathrm{T} 1$ & $0.003 \pm 0.00 \mathrm{a}$ & $0.012 \pm 0.002 \mathrm{a}$ & $6.04 \pm 0.00 \mathrm{a}$ & $12.41 \pm 1.19 \mathrm{a}$ & $0.04 \pm 0.00 \mathrm{a}$ & $0.36 \pm 0.05 \mathrm{a}$ & $0.14 \pm 0.00 \mathrm{a}$ & $2.80 \pm 0.2 \mathrm{a}$ \\
\hline $\mathrm{T} 2$ & $0.003 \pm 0.00 \mathrm{a}$ & $0.007 \pm 0.001 \mathrm{a}$ & $6.04 \pm 0.00 \mathrm{a}$ & $9.00 \pm 0.20 \mathrm{~b}$ & $0.04 \pm 0.00 \mathrm{a}$ & $0.23 \pm 0.06 \mathrm{a}$ & $0.14 \pm 0.00 \mathrm{a}$ & $2.02 \pm 0.32 \mathrm{a}$ \\
\hline $\mathrm{T} 3$ & $0.003 \pm 0.00 \mathrm{a}$ & $0.009 \pm 0.002 \mathrm{a}$ & $6.04 \pm 0.00 \mathrm{a}$ & $8.60 \pm 0.72 b$ & $0.04 \pm 0.00 \mathrm{a}$ & $0.35 \pm 0.07 \mathrm{a}$ & $0.14 \pm 0.00 \mathrm{a}$ & $2.41 \pm 0.26 \mathrm{a}$ \\
\hline $\mathrm{T} 4$ & $0.003 \pm 0.00 \mathrm{a}$ & $0.005 \pm 0.000 \mathrm{a}$ & $6.04 \pm 0.00 \mathrm{a}$ & $7.30 \pm 0.14 b$ & $0.04 \pm 0.00 \mathrm{a}$ & $0.31 \pm 0.07 \mathrm{a}$ & $0.14 \pm 0.00 \mathrm{a}$ & $2.26 \pm 0.08 \mathrm{a}$ \\
\hline
\end{tabular}

Table 2. continued

\begin{tabular}{|c|c|c|c|c|c|c|}
\hline \multirow{2}{*}{ Treatments } & \multicolumn{2}{|l|}{$\mathbf{K}^{+}$} & \multicolumn{2}{|l|}{$\mathrm{Ca}^{2+}$} & \multicolumn{2}{|l|}{$\mathrm{Mg}^{2+}$} \\
\hline & Beginning & End & Beginning & End & Beginning & End \\
\hline $\mathrm{T} 1$ & $4.82 \pm 0.00 \mathrm{a}$ & $13.18 \pm 0.52 \mathrm{a}$ & $1.20 \pm 0.00 \mathrm{a}$ & $9.41 \pm 0.30 \mathrm{a}$ & $1.21 \pm 0.00 \mathrm{a}$ & $3.51 \pm 1.5 b$ \\
\hline $\mathrm{T} 2$ & $4.82 \pm 0.00 \mathrm{a}$ & $10.35 \pm 0.64 a b$ & $1.20 \pm 0.00 \mathrm{a}$ & $3.66 \pm 0.56 b$ & $1.21 \pm 0.00 \mathrm{a}$ & $4.06 \pm 0.6 \mathrm{a}$ \\
\hline T3 & $4.82 \pm 0.00 \mathrm{a}$ & $8.97 \pm 0.70 b c$ & $1.20 \pm 0.00 \mathrm{a}$ & $7.83 \pm 0.21 \mathrm{a}$ & $1.21 \pm 0.00 \mathrm{a}$ & $3.61 \pm 1.5 b$ \\
\hline $\mathrm{T} 4$ & $4.82 \pm 0.00 \mathrm{a}$ & $10.37 \pm 0.60 \mathrm{ab}$ & $1.20 \pm 0.00 \mathrm{a}$ & $7.23 \pm 1.01 \mathrm{a}$ & $1.21 \pm 0.00 \mathrm{a}$ & $4.28 \pm 0.9 a$ \\
\hline
\end{tabular}


Table 3. Average value ( \pm standard errors) of water physical properties at the beginning and the end of the decomposition process of manure of pigs nourished with different types of diets

\begin{tabular}{lllllll}
\hline \multirow{2}{*}{ Treatments } & \multicolumn{2}{l}{ Suspended solids $\left(\mathbf{m g} . \mathbf{l}^{-1}\right)$} & pH & \multicolumn{3}{l}{ Temperature $\left({ }^{\circ} \mathbf{C}\right)$} \\
\cline { 2 - 7 } & Beginning & End & Beginning & End & Beginning & End \\
\hline T1 & $110.00 \pm 0.00 \mathrm{a}$ & $470.66 \pm 51.20 \mathrm{a}$ & $5.13 \pm 0.00 \mathrm{a}$ & $7.71 \pm 0.27 \mathrm{ab}$ & $30.10 \pm 0.00 \mathrm{a}$ & $33.77 \pm 0.24 \mathrm{a}$ \\
T2 & $110.00 \pm 0.00 \mathrm{a}$ & $571.00 \pm 60.79 \mathrm{a}$ & $5.13 \pm 0.00 \mathrm{a}$ & $7.69 \pm 0.33 \mathrm{ab}$ & $30.10 \pm 0.00 \mathrm{a}$ & $32.62 \pm 0.16 \mathrm{a}$ \\
T3 & $110.00 \pm 0.00 \mathrm{a}$ & $646.67 \pm 74.66 \mathrm{a}$ & $5.13 \pm 0.00 \mathrm{a}$ & $7.84 \pm 0.32 \mathrm{ab}$ & $30.10 \pm 0.00 \mathrm{a}$ & $32.33 \pm 0.26 \mathrm{a}$ \\
T4 & $110.00 \pm 0.00 \mathrm{a}$ & $453.33 \pm 42.20 \mathrm{a}$ & $5.13 \pm 0.00 \mathrm{a}$ & $8.14 \pm 0.23 \mathrm{a}$ & $30.10 \pm 0.00$ & $33.13 \pm 0.46 \mathrm{a}$ \\
\hline
\end{tabular}

Table 3. continued

\begin{tabular}{lllll}
\hline \multirow{2}{*}{ Treatments } & \multicolumn{2}{l}{ Dissolved $\mathbf{O}_{\mathbf{2}}\left(\mathbf{m g . ~}^{\mathbf{1}}\right)$} & \multicolumn{2}{l}{ Conductivity $\left(\boldsymbol{\mu}\right.$ S.cm $\left.^{-\mathbf{1}}\right)$} \\
\cline { 2 - 5 } & Beginning & End & Beginning & End \\
\hline T1 & $8.70 \pm 0.00 \mathrm{a}$ & $13.59 \pm 1.44 \mathrm{a}$ & $99.00 \pm 0.00 \mathrm{a}$ & $199.19 \pm 4.17 \mathrm{a}$ \\
T2 & $8.70 \pm 0.00 \mathrm{a}$ & $13.48 \pm 0.53 \mathrm{a}$ & $99.00 \pm 0.00 \mathrm{a}$ & $154.10 \pm 14.40 \mathrm{a}$ \\
T3 & $8.70 \pm 0.00 \mathrm{a}$ & $14.17 \pm 0.71 \mathrm{a}$ & $99.00 \pm 0.00 \mathrm{a}$ & $147.17 \pm 13.02 \mathrm{a}$ \\
T4 & $8.70 \pm 0.00 \mathrm{a}$ & $13.12 \pm 0.72 \mathrm{a}$ & $99.00 \pm 0.00 \mathrm{a}$ & $174.93 \pm 20.06 \mathrm{a}$ \\
\hline
\end{tabular}

Note: Means followed by the same letter are not significantly different $(\mathrm{P}>0.05)$ according to the Student Newman-Keuls test.
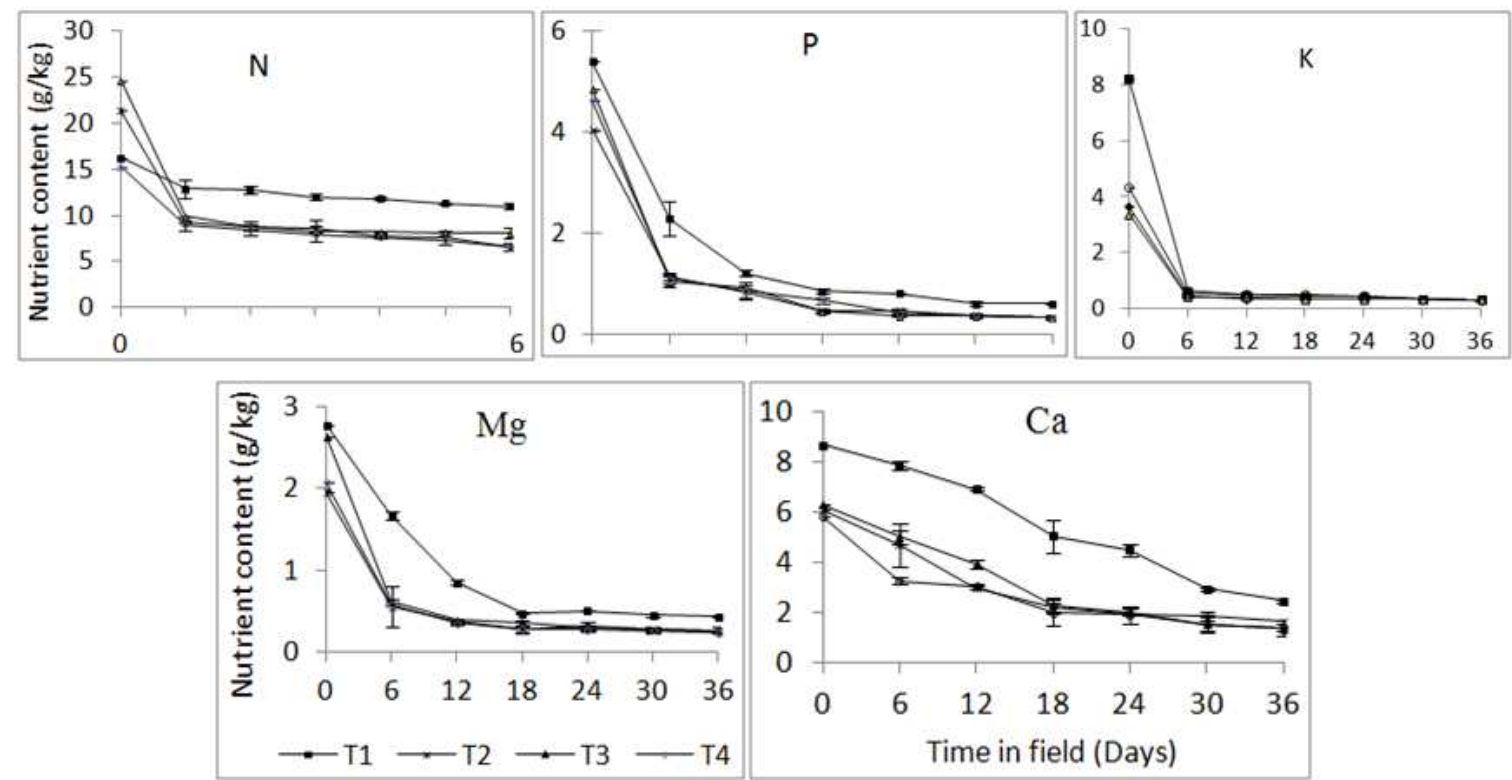

Figure 2. Changes in nutrient concentration $\left(\mathrm{g} \mathrm{kg}^{-1}\right)$ during decomposition process of manures from diets: (T1 = Manure of pigs nourished with recommended diet composition; T2 = manure of pigs nourished with diet partially improved with Azolla; T3 = manure of pigs nourished with diet improved with Azolla ; T4 = manure of pigs nourished with diet improved with cereal bran.

From our results, we observed that, only treatments $\mathrm{T} 1$ and T4 from diet enriched with few amount of Azolla filiculoides maintained a low $\mathrm{C}$ : $\mathrm{N}$ ratio during the experiment. However, Azolla contains $28.24 \%$ of lignin [27, 28] as consequence it may slow down the decomposition process of the organic residue. From this value, [29] reported that, $\mathrm{C}$ and $\mathrm{N}$ content regulate the early phase of decay while, lignin become more important for explanation thereafter. With treatments T2 and T3 diet containing 30\% and $47.5 \%$ respectively of Azolla filiculoides the $\mathrm{C}$ : $\mathrm{N}$ ratios were high after a week. These results corroborate with [24] results studying litters decomposition in the soil and found that, the slow decomposition is mainly caused by the very highest $C$ : $\mathrm{N}$ ratio due to the important lignin + polyphenol content in the residues. Furthermore, [19] reported also that, the amount of nutrient released can be correlated with $\mathrm{C}: \mathrm{N}: \mathrm{P}$ ratio. Manure from diet T3 has the highest value of $\mathrm{N}$ at the beginning and ongoing, these values become low due to the loss of $\mathrm{N}$.

$\mathrm{K}, \mathrm{Ca}$ and $\mathrm{Mg}$ values were high in treatment $\mathrm{T} 1$ but decreased over the weeks of experimentation. Our results indicate that, pig manure can supply all major nutrients $(\mathrm{N}, \mathrm{P}$, $\mathrm{K}, \mathrm{Ca}, \mathrm{Mg}$ ) for rice production in wetland. At the same way, [30] prove that, organic materials such as farmyards have traditionally been used by rice farmers. It supplies all major nutrients (N, P, K, Ca, Mg, S,) necessary for plant growth [31]. In wetland especially inland valley conditions where it was noticed from our result nitrogen loss by volatilization during the decomposition process, it is suggested for rice-fish production system to split manure supply.

\section{Conclusion}

From the present study we can conclude that, manure 
from diets T1 and T4 are an important source of nutrients $\mathrm{P}$, $\mathrm{K}, \mathrm{Ca}$ and $\mathrm{Mg}$. However, manure from diets $\mathrm{T} 3$ and $\mathrm{T} 2$ contained more $\mathrm{N}$ due to the addition of Azolla filliculoides $(47.5 \%$ and $30 \%)$ in the diet which had released an important quantity of $\mathrm{N}$ in the first week then after, leading to very weak concentration during the succeeding weeks of experiment. This important release of $\mathrm{N}$ could be harmful for rice production in wetland especially in the inland valley and having important nutrient demand during the growth period. Bases on these results, it is suggested for fish-rice production system pig manure from diet not too much rich in $\mathrm{N}$ in order to avoid $\mathrm{N}$ loss during the cropping period. When it comes to use this source of nutrient as strategy to improve crop production in the wetland or in the inland valley, it is suggested to split the amount of this organic manure to be applied according to the plant growth stage.

\section{Acknowledgements}

The authors are grateful to the "Scientific Council of the University of Abomey-Calavi in Benin" for funding the present research in the framework of the project "Optimization Integrated Agricultural Production System without Chemical Inputs (OPASISI)".

\section{References}

[1] F. Pilar, I. Castellar, and J. Navarro, "Nitrate leaching in pepper cultivation with organic manure and supplementary additions of mineral fertilizer". Communications in Soil Science and Plant Analysis, 36: 2889-2899, 2005.

[2] R.F. Follett, and J.A. Delgado,"Nitrogen fate and transport in agricultural systems." Journal of Soil and Water Conservation, 57: 402-408, 2002.

[3] M. Kaleem, A. Abbasi, H. Munazza, K. Abdul, and S. R. Khan, "Mineralization of three organic manures used as nitrogen source in a soil incubated under laboratory conditions." Communications in Soil Science and Plant Analysis, 38:13-14, 1691-1711. 2007.

[4] M.P. Bernal, J.A. Albuquerque, and R. Moral, "Composting of animal manures and chemical criteria for compost maturity assessment". A review. Bioresource Technology 100, 5444-5453, 2009.

[5] M. Inckel, S. Peter, T. Tersmette, and T. Veldskamp, "Fabrication et utilisation du compost." Série AgroDoc. №8 : $71 \mathrm{p} ., 2007$.

[6] E. Vasconcelos, F. Cabral, and C.M.D.S. Cordovil, "Wheat yield and leachability of phosphorus and nitrogen in pig slurry amended soils." Communications in Soil Science and Plant Analysis, 30: 2245-2257, 1999.

[7] N. Vagstad, A. Broch-Due, and I. Lyngstad, "Direct and residual effects of pulp and paper mill sludge on crop yield and soil mineral N". Soil Use Management, 17: 173-178, 2001.

[8] G.W. Evers, "Ryegrass-Bermuda grass production and nutrient uptake when combining nitrogen fertilizer with broiler litter.” Agronomic Journal, 94, 905-910, 2002.

[9] C.M.D.S. Cordovil, F. Cabral, and J. Coutinho, "Potential mineralization of nitrogen from organic wastes to ryegrass and wheat crops". Bioresource Technology 98, 3265-3268, 2007.

[10] L.G. Amadji, A. Saïdou and L. Chitou, "Recycling of organic residues in compost to improve coastal sandy soil properties and cabbage shoot in Benin." International Journal of Biological and Chemical Sciences, 3(2): 192 - 202, 2009.

[11] G.F. Huang, J.W.C. Wong, Q.T. Wu, and B.B. Nagar, "Effect of $\mathrm{C} / \mathrm{N}$ on composting of pig manure with sawdust." Waste Management, 24: 805-813, 2004.

[12] L. Jianbo, and L. Xia, "Review of rice-fish-farming systems in China One of the Globally Important Ingenious Agricultural Heritage Systems (GIAHS)." Aquaculture, 260: 106-113, 2006.

[13] A.K.Y Haroon, and K.A. Pittman, "Rice-fish culture: feeding, growth and yield of two size classes of Puntius gonionotus Bleeker and Oreochromis spp. in Bangladesh." Aquaculture, 154: 26 1-281, 1997.

[14] A.Youssouf, A. Saidou, D. Mama, E.D Fiogbé and J-C. Micha, "Evaluation of nitrogen and phosphorus wastes produced by Nile Tilapia (Oreochromis niloticus L.) Fed Azolla-diets in earthen ponds." Journals of Environmental Protection, 3: 502-507, 2012.

[15] E.D. Fiogbé, and K.H. Gangbazo, "Production porcine avec Azolla." Actes des $2^{\text {èmes }}$ Journées Scientifiques Internationales des Universités Nationales du Bénin. (13-16 avril 2004); 142-154, 2005.

[16] J-M.M. Accodji, E.D. Fiogbé, and K.H. Gangbazo, "Essai de valorisation d'Azolla (Azolla microphylla Kaulf) dans la production porcine en zone humide." International Journal of Biological and Chemical Sciences, 3(5) : 890 - 898, 2009.

[17] H. Agadjihouèdé, E. Montchowi, A. Chikou, and P.A Lalèyè, 'Libération comparée de sels dans l'eau par la minéralisation de l'Azolla, la bouse de vache, la fiente de volaille et les sons de riz et de maïs utilisés en pisciculture." International Journal of Biological and Chemical Sciences, 5(5): 1883-1897, 2011.

[18] S. Qiu, A.J. Mc Comb, and R.W. Bell, "Leaf litter decomposition and nutrient dynamics in woodland and wetland conditions along a forest to wetland hill slope." International Scholarly Research Network. ISRN Soil Science. Vol 12, ID346850, 8 p., 2012.

[19] J. Rodier, "L'Analyse de l'eau. eaux naturelles, eaux résiduelles, eau de mer." $8^{\text {ème }}$ édition DUNOD, 1383p., Juin 1996.

[20] E.A. Hartemink and J.N. O' Sullivan, "Leaf litter decomposition of Piper aduncum, Gliricidia sepium, and Imperata cylindrica in the humid lowland of Papua New Guinea." Plant and Soil, 230: 115 - 124, 2001.

[21] G.L. Godshalk, "Decomposition of aquatic plants in lakes". PhD. Thesis, Michigan State University. Department Botany and Plant pathology: 49-61, 1977.

[22] J. Kortleven, "Quantitative aspects of humus accumulation and decomposition." Landbk, Onderz. 69. 1. Pudoc, Wageningen. 109 pp, 1963. 
[23] C-H. Wang, "Effects of different organic materials on crop production under a rice-corn cropping sequence." Communications in Soil Science and Plant Analysis, 44 : 2987-3005, 2013.

[24] M.K. Abbasi, M. Hina, K.A. Abdul, and S.R. Khan, "Mineralization of three organic manures used as nitrogen source in a soil incubated under laboratory conditions." Communications in Soil Science and Plant Analysis, 38: 1691-1711, 2007.

[25] R. Hassan, E. Khadija, D. Belghyti, and M. Hadji, "Physico-chemical waste water unit of sugar SUNABEL Mechraa Belksiri”. ScienceLib Editions Mersenne : Volume $5, \mathrm{~N}^{\circ} 130215,2111-4706,2013$.

[26] E.D. Fiogbé, I. Imorou Toko, J-C. Micha, and C.H.F Van Hove "Azolla : une fougère aquatique utilisable comme intrant pour diversifier et intégrer les productions agro-piscicoles des zones humides." Journée scientifique à l’Université Nationale du Bénin, 2001.
[27] A.Z.K. Djogbédé, L.C. Hinvi, E.D. Fiogbé, "Effets de substitution des engrais chimiques par Azolla pinnata en riziculture au Nord Bénin." International Journal of Biological and Chemical Sciences, 6(6) : 3027-3044, 2012.

[28] C.K.H. Smith, L. Gholz and F. De Assis Oliveira, "Fine litter chemistry, early-stage decay, and nitrogen dynamics under plantations and primary forest in lowland Amazonia." Soil Biology \& Biochemistry, 30(14): 2159-2169. 1998.

[29] T. Tilahun, D. Nigussie, B. Wondimu, and G. Setegn, "Effects of farmyard manure and inorganic fertilizer application on soil physico-chemical properties and nutrient balance in rain-fed lowland rice ecosystem". American Journal of Plant Sciences, 4, 309-316, 2013.

[30] G. Villegas-Pangga,“Agri-wastes for soil productivity improvement in a lowland rice ecosystem." Symposium on agricultural and agro-industrial waste management, march 12-14, Sao Pedro, sp, Brazil, 2013. 